\title{
Triple peptide vaccination as consolidation treatment in women affected by ovarian and breast cancer: Clinical and immunological data of a phase $\mathbf{I} / \mathbf{I I}$ clinical trial
}

\author{
MORENA ANTONILLI $^{1 *}$, HASSAN RAHIMI $^{2 *}$, VALERIA VISCONTI ${ }^{2 *}$, CHIARA NAPOLETANO $^{2}$, \\ ILARY RUSCITO ${ }^{1}$, ILARIA GRAZIA ZIZZARI ${ }^{2}$, SALVATORE CAPONNETTO ${ }^{2}$, GIACOMO BARCHIESI ${ }^{2}$, \\ ROBERTA IADAROLA ${ }^{1}$, LUCA PIERELLI ${ }^{2}$, AURELIA RUGHETTI ${ }^{2}$, FILIPPO BELLATI ${ }^{1}$, \\ PIERLUIGI BENEDETTI PANICI ${ }^{1}$ and MARIANNA NUTI ${ }^{2}$
}

${ }^{1}$ Department of Gynecology, Obstetrics and Urology, ${ }^{2}$ Department of Experimental Medicine, 'Sapienza' University of Rome, Policlinico Umberto I, 00161 Rome, Italy

Received November 5, 2015; Accepted January 13, 2016

DOI: 10.3892/ijo.2016.3386

\begin{abstract}
Vaccination with priming and expansion of tumour reacting $\mathrm{T}$ cells is an important therapeutic option to be used in combination with novel checkpoint inhibitors to increase the specificity of the $\mathrm{T}$ cell infiltrate and the efficacy of the treatment. In this phase I/II study, 14 high-risk disease-free ovarian (OC) and breast cancer (BC) patients after completion of standard therapies were vaccinated with MUC1, ErbB2 and carcinoembryonic antigen (CEA) HLA-A2 $2^{+}$-restricted peptides and Montanide. Patients were subjected to 6 doses of vaccine every two weeks and a recall dose after 3 months. ECOG grade 2 toxicity was observed at the injection site. Eight out of 14 patients showed specific $\mathrm{CD}^{+} \mathrm{T}$ cells to at least one antigen. None of 4 patients vaccinated for compassionate use showed a CD8 activation. An OC patient who suffered from a lymph nodal recurrence, showed specific anti-ErbB2 CD8 ${ }^{+}$ $\mathrm{T}$ cells in the bulky aortic lymph nodes suggesting homing
\end{abstract}

Correspondence to: Professor Marianna Nuti, Laboratory of Tumour Immunology and Cell Therapy, Department of Experimental Medicine 'Sapienza' University of Rome, Policlinico Umberto I, 00161 Rome, Italy

E-mail:marianna.nuti@uniroma1.it

*Equally contributed

Abbreviations: AKP, alkaline phosphatase; CEA, carcinoembryonic antigen; CTL, cytotoxic T lymphocytes; DFS, disease-free survival; DTH, delayed time hypersensitivity; EC, Ethics Committee; EGF, epithelial growth factor; EOCG, Eastern Cooperative Oncology Group; GMP, good manufacturing practice; INIH, Italian National Institute of Health; KLH, keyhole limpet hemocyanin; OS, overall survival; PBMCs, peripheral blood mononuclear cells; SC, subcutis; TAAs, tumour associated antigens; Treg, regulatory T cells

Key words: peptide-based vaccination, MUC1/ErbB2/CEA, ovarian cancer, breast cancer, immunotherapy of the activated $\mathrm{T}$ cells. Results confirm that peptide vaccination strategy is feasible, safe and well tolerated. In particular OC patients appear to show a higher response rate compared to $\mathrm{BC}$ patients. Vaccination generates a long-lasting immune response, which is strongly enhanced by recall administrations. The clinical outcome of patients enrolled in the trial appears favourable, having registered no deceased patients with a minimum follow-up of 8 years. These promising data, in line with the results of similar studies, the high compliance of patients observed and the favourable toxicity profile, support future trials of peptide vaccination in clinically disease-free patients who have completed standard treatments.

\section{Introduction}

Advanced breast cancer (BC) and ovarian cancer (OC) are two of the most lethal gynaecologic malignancies in developed countries (1). Median survivals are 15 months for metastatic breast cancer (2) and 57 months for stage III ovarian cancer (3). In $\mathrm{BC}$, current consolidation treatments include monoclonal antibodies (4) and hormonetherapy (5). In OC, several trials have attempted to introduce consolidation chemotherapy regimens, but up to now, no treatment has shown by direct comparison to improve overall survival in randomized trials (6). There is plenty of evidence that prove the strong relationship between these two neoplasms and the immune system and therefore tumour response or progression is likely to be partially dictated by the host immune status. Both OC and BC are able to elicit spontaneous immune responses (7-9) and antigen targeted immunotherapy represents an extremely attractive strategy that could be added to conventional treatments.

Several tumour-associated antigens (TAAs) have been identified as possible targets in BC and OC. The mucin MUC1 is a highly glycosylated type I transmembrane glycoprotein that is aberrantly glycosylated during tumour progression. It is expressed in BC and OC tissues in over $90 \%$ of the cases. The carcinoembryonic antigen (CEA) belongs both to the oncofetal and $\operatorname{IgG}$ supergene family. It is expressed during oncofetal life 
and in normal colonic mucosa. In tumours, CEA is overexpressed in 50 and $60 \%$ of $\mathrm{BC}$ and $\mathrm{OC}$, respectively. The ErbB2 oncogene belongs to the epidermal growth factor (EGF) family. It is overexpressed in $20-30 \%$ of breast and ovarian neoplasms.

Over the last decades, several trials on vaccination in $\mathrm{BC}$ and $\mathrm{OC}$ have been carried out with disappointing results. We have recently shown that tumour debulking is able to partially revert tumour-induced immune suppression (10). Most past trials have enrolled heavily pretreated women with high tumour burden. Currently, several authors have stated that vaccination therapies may show their highest efficacy in patients with low tumour burden and with the immune system that has not been heavily compromised by previous cytotoxic therapies (11).

Here we report the results of an escalating phase I/II safety trial carried out with CEA (YLSGADLNL), ErbB2 (KIFGSLAFL) and MUC1 (SAPDNRPAL) peptides in high-risk patients in clinical remission of disease who have completed standard treatment. Furthermore, heavily pretreated patients affected by advanced recurrent tumours were treated in a 'compassionate setting' with the same vaccination schedule. Immunological data from this sample of patients were used to verify the relevance of timing for the efficacy of immunological interventions.

Vaccination leading to priming and expansion of tumour reacting $\mathrm{T}$ cells can be an important therapeutic option to be used in combination with checkpoint inhibitors such as antiCTLA4 and anti-PD1, to increase the specificity of the T cell infiltrate repertoire and subsequently the efficacy of treatment.

\section{Materials and methods}

Patients. This open-label phase I/II safety clinical trial was approved by Policlinico Umberto I Ethics Committee (EC) and Italian National Institute of Health (INIH) (protocol $\mathrm{n}^{\circ}$ LITRM/DIMIGE05/01). Patients were recruited from the Gynaecologic and Obstetrics Department of University of Rome 'Sapienza' from May 2007 to January 2009. Inclusion criteria were: i) BC or OC who had completed gold standard treatment forecast for their tumour type and stage; ii) positive for the HLA-A2 haplotype; iii) written informed consent, and iv) performance status accordingly to the 'Eastern Cooperative Oncology Group' (ECOG) between 0-2. Exclusion criteria were: i) age $\leq 18$ and $\geq 70$ years; ii) history of autoimmune disease; iii) previous malignancy; iv) ongoing HIV, HBV or HCV infection; v) use of immunosuppressive drugs; vi) pregnancy and breastfeeding and vii) any heart, liver, kidney or psychiatric diseases. Furthermore 4 women affected by progressive, recurrent disease, with EC approval, were treated with the same vaccination schedule for compassionate use and their data are also reported.

Study design and amendments. The study was performed as a feasibility and safety phase I/II trial. On the basis of the extreme tolerance and low magnitude of the side effects shown by the first 8 patients according to protocol; in line with emerging literature suggesting higher immunological responses of higher peptide vaccination doses $(12,13)$, the study was amended and transitioned to phase II and the last
6 patients according to protocol were vaccinated with a high dose regimen. In addition a primary efficacy end point of recurrence was added at 36 months.

Three patients vaccinated for compassionate use were vaccinated with a low dose regimen whereas one woman was vaccinated with the high dose regimen.

One vaccinated ovarian cancer patient treated according to protocol suffered a lymph nodal recurrence and was subjected to para-aortic lymphadenectomy followed by 3 re-boosts concomitantly to II line adjuvant chemotherapy.

Vaccination was started within 6 months of completion of chemotherapy. Thirty days of interval between the last dose of adjuvant treatment and enrolment were required. Timing of vaccination, blood sampling and delayed time hypersensitivity (DTH) are shown in Fig. 1. Briefly, the treatment schedule consisted in 6 consecutive doses administered every two week followed by a further recall dose at 3 months from the last dose. Vaccination was carried out subcutis (s.c.) in the inguinal area. Before and after vaccination, all patients were skin tested with Keyhole Limpet Hemocyanin (KLH) (Intracel, Frederick, MA, USA), in order to confirm patient's immune competence.

Vaccine composition. Three HLAI-A2 restricted peptides adopted for vaccination were: $\mathrm{MUC1}_{159-167}$ (SAPDNRPAL), ErbB2 $_{368-377}$ (KIFGSLAFL) and $\mathrm{CEA}_{605-613}$ (YLSGADLNL). The peptides were commercially produced in good manufacturing practices grade (GMP) by Clinalfa Merck Biosciences (Läufelfingen, Switzerland). The vaccine always contained MUC1 peptide, whereas CEA and ErbB2 peptides were added to the vaccine on the basis of immunohistochemical staining. Low and high dose peptides were 100 and $500 \mu \mathrm{g}$, respectively. The vaccine also contained $1 \mathrm{ml}$ Montanide ISA 51 (Seppic, Paris, France) as adjuvant and GM-CSF (Gentaur, Kampenhout, Belgium) $100 \mu \mathrm{g}$. In addition to the vaccine, $100 \mu \mathrm{g}$ of $\mathrm{KLH}$ were s.c. administered on the contralateral inguinal area as immunological tracker.

Collection of peripheral blood mononuclear cells (PBMCs). Blood withdrawals $(50 \mathrm{ml})$ were carried out before the first vaccination dose, after the sixth vaccination and after the recall dose (Fig. 1). PBMCs were isolated by density-gradient centrifugation technique (Ficoll-Hypaque, Cederlane, The Netherlands) and were cryopreserved until use.

$T$ cell stimulation in vitro. Thawed PBMCs from patients were in vitro pre-sensitized with $\mathrm{MUC1}_{159-167}, \mathrm{ErbB}_{368-377}$ and $\mathrm{CEA}_{605-613}$ peptide-pulsed K562-A*0201 cells (kindly provided by Dr T. Wolfel, University of Mainz) as previously described (14). Briefly, K562-A*0201 cells were pulsed for $1 \mathrm{~h}$ with $10 \mu \mathrm{g} / \mathrm{ml}$ of peptide (Clinalfa Merck Biosciences), then irradiated (30 Gy, X-RayCell Irradiator) and co-coltured with PBMCs to the ratio 1:30 without any additional wash. Cells were suspended in RPMI-1640, penicillin $100 \mathrm{U} / \mathrm{ml}$, streptomycin $100 \mu \mathrm{g} / \mathrm{ml}$, glutamine $2 \mathrm{mM}$ (all from EuroClone), $\beta$-mercaptoethanol $50 \mathrm{mM}$ (Sigma-Aldrich, St. Louis, MO, USA), 10\% FCS (Biowest) [complete medium (CM)], IL-2 $10 \mathrm{U} / \mathrm{ml}$ (PreproTech Inc., Rocky Hill, NJ, USA) and rIL-15 $10 \mathrm{ng} / \mathrm{ml}$ (R\&D, Minneapolis, MN, USA). Cytokines were added at day 3,7 and 10 . At day 11, cells were harvested and 


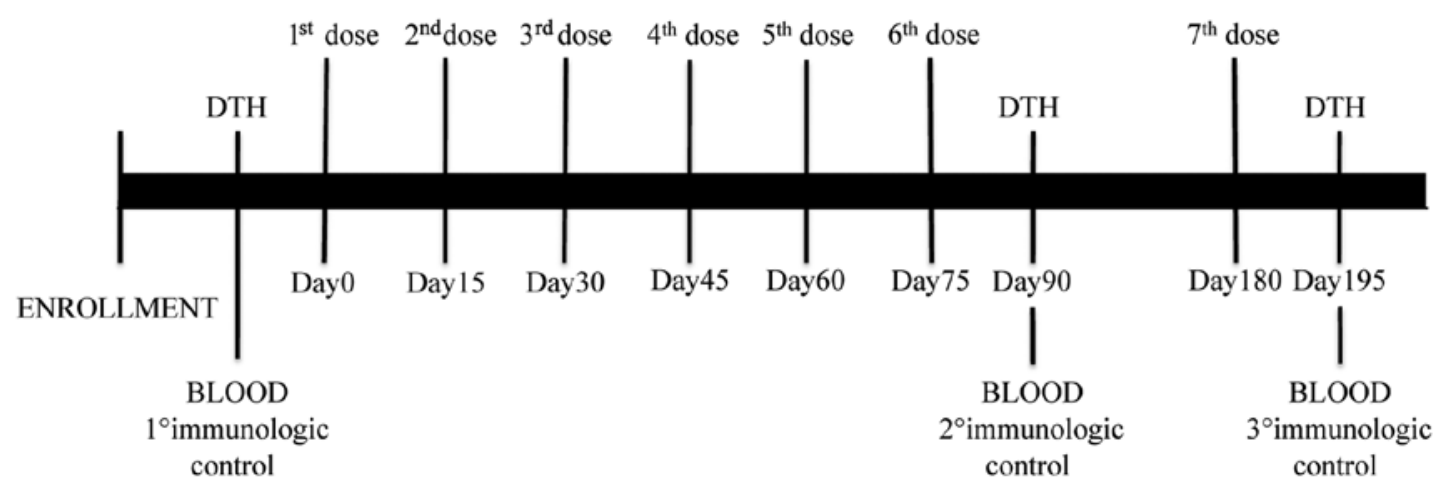

Figure 1. Vaccination schedule. Patient received 6 consecutive doses of vaccine every two weeks followed by a further recall dose (7th dose) at 3 months from the last dose. Before and after vaccination, and after the recall dose, patients were subjected to DTH.

$\mathrm{CD}^{+}$were purified using CD8 microbeads (MiltenyiBiotec, Gladbach, Germany).

Pentamer staining. Amplified CD8 ${ }^{+}$lymphocytes were analysed with ErbB2, MUC1 and CEA pentamers (PE) (Proimmune, Oxford, UK) according to the manufacturer's instructions. Concurrently, cells were stained with anti-CD8 PE-Cy5 (clone RPA T8) and anti-CD3 FITC (clone UCHT1) (both from BD Biosciences, San Diego, CA, USA) antibodies.

ELISPOT assay. Multiscreen IPVH plates (Millipore, Bedford, MA, USA) were coated with $10 \mu \mathrm{g} / \mathrm{ml}$ of $\mathrm{mAb}$ anti-human IFN $\gamma$ (BD Bioscience) in PBS w/o Ca ${ }^{++} / \mathrm{Mg}^{++}$and plated overnight at $4^{\circ} \mathrm{C}$. After blocking, $\mathrm{CD}^{+}$antigen specific $\mathrm{T}$ cells $\left(1 \times 10^{5} /\right.$ well $)$ were plated in triplicate with irradiated (30 Gray) autologous PBMCs, derived from pre-vaccination withdrawal, pulsed with MUC1, ErbB2 or CEA peptide. Cells were removed 16 to $20 \mathrm{~h}$ later. Spots of IFN $\gamma$ were detected by adding biotinylated anti-IFN $\gamma$ antibody $\left(5 \mu \mathrm{g} / \mathrm{ml}, 2 \mathrm{~h}\right.$ at $\left.37^{\circ} \mathrm{C}\right)$ followed by AKP-streptavidin conjugate $\left(1: 1,000,2 \mathrm{~h}\right.$ at $\left.37^{\circ} \mathrm{C}\right)$ (both from BD Bioscience) and chromogen substrate (BCIP/ NBT Alkaline Phosphatase Substrate; Sigma) (50 $\mu \mathrm{l} /$ well). Spots were counted using the ImmunoSpot Image Analyzer (Aelvis, Germany). Results were evaluated by subtracting the median number of spots of the negative samples (unpulsed DCs + CD8 T cells) from median number of spots of the study samples (peptide pulsed DCs + CD8 T cells). In order to consider a sample evaluable a minimum of 20 spots above the background was considered. The results were analyzed as fold increase of the calculated values (after vaccination/before vaccination). Median and range values of IFN $\gamma$ spots were calculated on the overall values of the three peptides. A vaccine induced CD8 $\mathrm{T}$ cell response was defined as at least 2 -fold increase in the IFN $\gamma$ production of CD8 T cells from the last dose from the pre-vaccination samples.

Flow cytometry. Cell labelling was performed using the following monoclonal antibodies: anti-CD4 FITC (clone RPA T4), anti-CD45RA APC (clone HI100), anti-CD25 PE (clone M-A251), and anti-FOXP3 Alexa 647 (clone 259D/C7) (all from BD Biosciences). For the FOXP3 intracellular staining, cells were permeabilized with Human FoxP3 Buffer (BD Biosciences). Cell phenotype was evaluated using
FACSCanto II flow cytometer running FACSDiva data acquisition and analysis software (both from Becton Dickinson).

Delayed time hypersensitivity (DTH). DTH reaction was used to evaluate the cellular immune response at different time-points of vaccination in vivo (Fig. 1). The assay was performed by separate intradermal injection in the region anti-brachioradialis of $10 \mu \mathrm{g}$ of MUC1, ErbB2, CEA peptides (Clinalfa Merck Biosciences) and KLH (Intracell). Positivity was assessed 48-72 $\mathrm{h}$ later and compared to the control.

Toxicity. The ECOG Common Toxicity Criteria (version, June 15, 2007) definition of toxicity events was applied. Patients were controlled, at all doses, for both local and systemic adverse events. By study design, progression to second phase occured if no significant toxicity was registered in the first eleven patients.

Clinical follow-up. Since the enrolment all patients were screened for recurrence by: physical, laboratory and imaging exams performed every 3 months in the absence of any new symptoms. Follow-up was closed after a median of 87 months, in July 2015.

Statistical analysis. Data were analysed using STATA11 (StataCorp LP, College Station, College Station, TX, USA). A Fisher's exact test was used to examine the significance of the association of the dichotomous outcomes. Significance is indicated when the $p$-value is $<0.05$.

\section{Results}

Patients. Between 2007 and 2009, 14 patients (7 BC and 7 OC women) were enrolled in this trial and treated according to the protocol. In addition, 4 patients (1 BC and 3 OC) affected by recurrent/metastatic disease requested vaccination for compassionate use and were subjected to the same treatment. Immunological data from the latter patients are also described and used for comparison. Characteristics of all the patients are summarized in Table I.

Briefly, the average age of all enrolled patients was 53 (sd, 9,9; range, 42-70 years old). BC patients were mostly affected by infiltrating ductal breast carcinoma. ErbB2 
Table I. Patient characteristics.

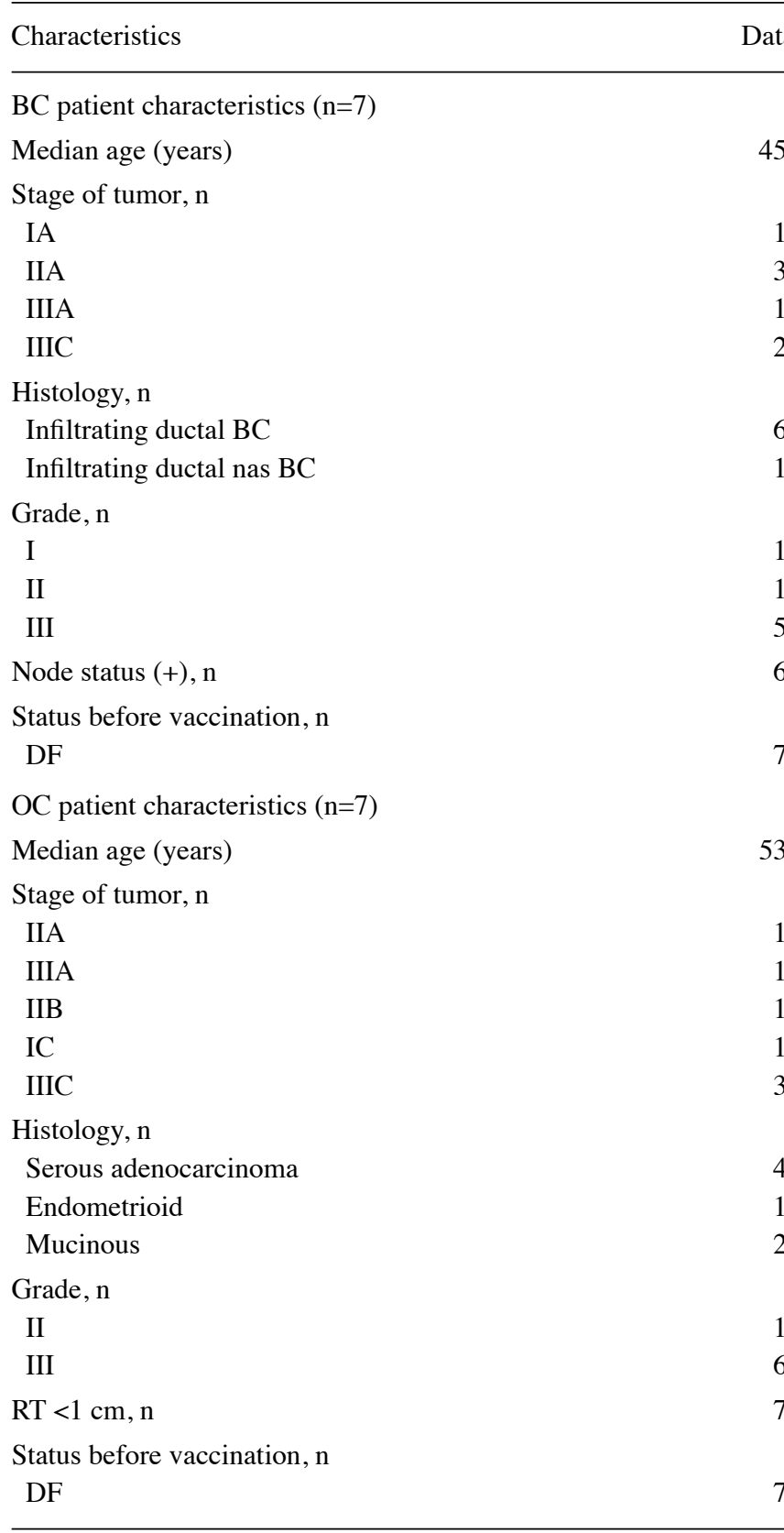

\begin{tabular}{|c|c|c|}
\hline & OC (3 pzs) & $\mathrm{BC}(1 \mathrm{pz})$ \\
\hline \multicolumn{3}{|c|}{ Patient characteristics (compassionate use) $(n=4)$} \\
\hline Median age & 60 years & 40 years \\
\hline Stage of tumor & IIIC (2 pzs); IIB (1 pz) & IV \\
\hline Histology & $\begin{array}{c}\text { Serous } \\
\text { adenocarcinoma }(3 / 3)\end{array}$ & $\begin{array}{l}\text { Infiltrating } \\
\text { ductal BC }\end{array}$ \\
\hline Grade & III $(3 / 3)$ & III \\
\hline $\begin{array}{l}\text { Status before } \\
\text { vaccination }\end{array}$ & $\mathrm{SD}(2 \mathrm{pzs}) ; \mathrm{PD}(1 \mathrm{pz})$ & $\mathrm{PD}$ \\
\hline
\end{tabular}

DF, disease-free; SD, stable disease; PD, progression disease; RT, tumor residual.

expression was $3^{+}$in $57 \%$ of the patients and $2^{+}$in $43 \%$, half of the women had $<3$ positive lymph nodes. CEA and
MUC1 tumour expression was respectively 71 and $100 \%$. Half of the OC cases were serous adenocarcinoma at diagnosis, most women were affected by scarcely differentiated neoplasms, FIGO stage III and optimally debulked (residual tumour $<1 \mathrm{~cm}$ ). Platinum-based adjuvant chemotherapy was successively administered to all OC patients. CEA, ErbB2 and MUC1 expression was, respectively, 43, 43 and 100\%. CA-125 levels were routinely monitored in all ovarian cancer patients and resulted below range of positivity also for patient OV04 and OV011 who experienced a recurrence.

Two OC patients treated for compassionate use had been subjected to secondary cytoreduction and adjuvant platinum based second line chemotherapy. These patients were in clinical remission at the beginning of immunotherapy. The last OC patient suffered from peritoneal disease progression after tumour debulking and three lines of chemotherapy. The $\mathrm{BC}$ patient, treated in a compassionate setting, was a woman affected by pleural, brain, hepatic and bone recurrence after treatment with taxane, trastuzumab, lapatinib and capecitabine.

All 14 enrolled patients completed the vaccination regimen receiving the 6 doses of vaccine and the additional recall dose. Of these, 6 women received a high dose regimen. Therefore 84 vaccinations (36 high dose) were carried out with their 14 planned recall doses in this setting.

Three out of 4 patients undergoing vaccination for compassionate use received a low dose regimen and one the high dose, while one out of 3 patients completed the low dose vaccination protocol with the recall dose. One patient completed the low dose vaccination protocol, but did not carry out the recall dose due to disease progression. One patient suspended treatment after the third vaccination for disease progression. One patient completed the high dose vaccination protocol and carried out the recall dose.

Evaluation of the immune response. Before vaccination, no enrolled patient had a specific IFN $\gamma$ producing $\mathrm{CD}^{+}$immune response. At the end of the treatment, $8 / 14$ patients showed a specific IFN $\gamma$ producing $\mathrm{CD}^{+}{ }^{+}$immune response to at least one antigen (Tables II and III). None of the 4 patients vaccinated for compassionate use showed an activation of $\mathrm{CD}^{+}$specific lymphocyte before or after vaccination (Table IV).

Among responding patients, $2 / 7$ were $\mathrm{BC}$ whereas $6 / 7$ were $\mathrm{OC}$. Highest response rates were detected after the completion of the six administrations. Peptide vaccination was effective in inducing an immune response in 3/14, 4/10 and 4/7 for MUC1, ErbB2 and CEA, respectively. The low dose and high dose regimen induced a response in respectively $5 / 8$ and $3 / 6$ patients. In Fig. 2, patient immune response to the antigenic peptides is presented as ratio between the IFN $\gamma$ spots obtained after and before vaccination.

The median background of IFN $\gamma$ spots of negative control samples (unpulsed DCs + CD8 T cells) was 23 (range, 8-178) before vaccination and 19 (range, 8-118) after vaccination. The median values of IFN $\gamma$ spots of study samples (peptide pulsed DCs + CD8 T cells) before and after vaccination were 19 (range, 7-296) and 42.5 (range, 8-598), respectively. Data (median and range) of the single peptide are summarized in Table V.

A vaccine-induced CD8 $\mathrm{T}$ cell response was defined as at least 2 -fold increase in the IFN $\gamma$ production of CD8 T cells from the last vaccination dose from the pre-vaccination samples. 


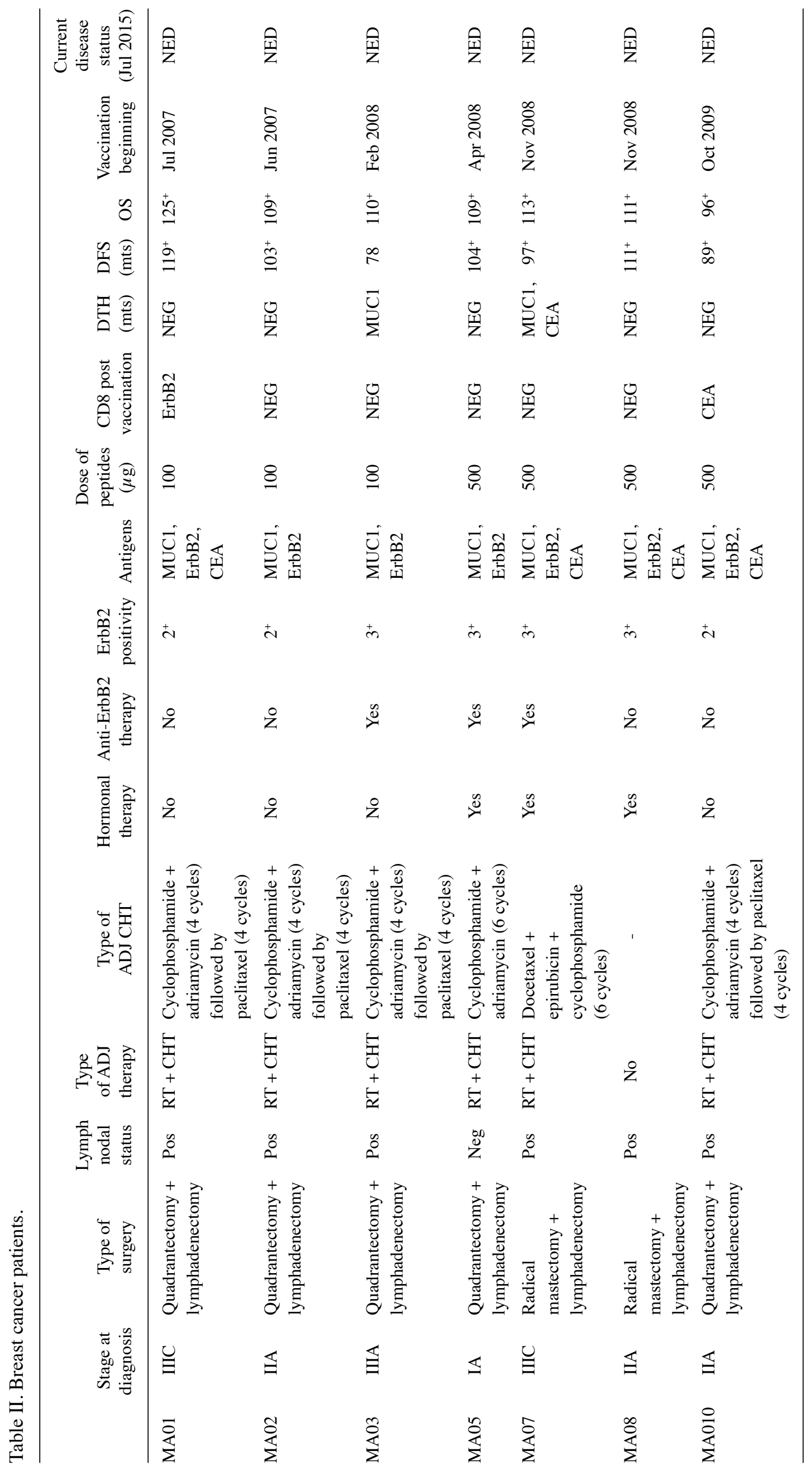


Table III. Ovarian cancer patients.

\begin{tabular}{|c|c|c|c|c|c|c|c|c|c|c|c|}
\hline & $\begin{array}{c}\text { Stage at } \\
\text { diagnosis }\end{array}$ & $\begin{array}{l}\text { Type of } \\
\text { surgery }\end{array}$ & $\begin{array}{c}\text { Type of } \\
\text { ADJ CHT }\end{array}$ & Antigens & $\begin{array}{c}\text { Dose of } \\
\text { peptides } \\
(\mu \mathrm{g})\end{array}$ & $\begin{array}{c}\text { CD8 post } \\
\text { vaccination }\end{array}$ & DTH & $\begin{array}{c}\text { DFS } \\
\text { (months) }\end{array}$ & $\begin{array}{c}\text { OS } \\
\text { (months) }\end{array}$ & $\begin{array}{c}\text { Vaccination } \\
\text { beginning }\end{array}$ & $\begin{array}{c}\text { Current } \\
\text { disease status } \\
\text { (July 2015) }\end{array}$ \\
\hline OV01 & IIA & $\begin{array}{l}\text { Primary } \\
\text { cytoreduction }\end{array}$ & $\begin{array}{l}\text { Carboplatin }+ \\
\text { paclitaxel } \\
(6 \text { cycles })\end{array}$ & MUC1 & 100 & MUC1 & MUC1 & 87 & $102^{+}$ & Jul 2007 & NED \\
\hline OV04 & IIIC & $\begin{array}{l}\text { Primary } \\
\text { cytoreduction }\end{array}$ & $\begin{array}{l}\text { Carboplatin }+ \\
\text { paclitaxel } \\
(6 \text { cycles })\end{array}$ & MUC1 & 100 & NEG & NEG & 18 & $109^{+}$ & Sep 2007 & PD \\
\hline OV05 & IIIC & $\begin{array}{l}\text { Primary } \\
\text { cytoreduction }\end{array}$ & $\begin{array}{l}\text { Carboplatin }+ \\
\text { paclitaxel } \\
(6 \text { cycles })\end{array}$ & MUC1 & 100 & MUC1 & NEG & $128^{+}$ & $133^{+}$ & Sep 2007 & NED \\
\hline OV06 & IC & $\begin{array}{l}\text { Primary } \\
\text { cytoreduction }\end{array}$ & $\begin{array}{l}\text { Carboplatin }+ \\
\text { paclitaxel } \\
(5 \text { cycles })\end{array}$ & $\begin{array}{l}\text { MUC1, } \\
\text { CEA }\end{array}$ & 100 & CEA & CEA & $114^{+}$ & $122^{+}$ & Dec 2007 & NED \\
\hline OV07 & IIIA & $\begin{array}{l}\text { Primary } \\
\text { cytoreduction }\end{array}$ & $\begin{array}{l}\text { Carboplatin }+ \\
\text { paclitaxel } \\
(6 \text { cycles })\end{array}$ & $\begin{array}{l}\text { MUC1, } \\
\text { ErbB2 }\end{array}$ & 100 & ErbB2 & NEG & $96^{+}$ & $101^{+}$ & Jan 2008 & NED \\
\hline OV010 & IIIC & $\begin{array}{l}\text { Primary } \\
\text { cytoreduction }\end{array}$ & $\begin{array}{l}\text { Carboplatin }+ \\
\text { paclitaxel } \\
(6 \text { cycles })\end{array}$ & $\begin{array}{l}\text { MUC1, } \\
\text { ErbB2, } \\
\text { CEA }\end{array}$ & 500 & $\begin{array}{l}\text { MUC1, } \\
\text { ErbB2, } \\
\text { CEA }\end{array}$ & NEG & $104^{+}$ & $111^{+}$ & Sep 2008 & NED \\
\hline OV011 & IIB & $\begin{array}{l}\text { Primary } \\
\text { cytoreduction }\end{array}$ & $\begin{array}{l}\text { Carboplatin }+ \\
\text { paclitaxel } \\
(6 \text { cycles })\end{array}$ & $\begin{array}{l}\text { MUC1, } \\
\text { ErbB2, } \\
\text { CEA }\end{array}$ & 500 & $\begin{array}{l}\text { ErbB2, } \\
\text { CEA }\end{array}$ & ErbB2 & $94^{+}$ & $99^{+}$ & Jan 2009 & NED \\
\hline
\end{tabular}

Table IV. Characteristics of patients vaccinated for compassionate use.

\begin{tabular}{lcccccccc}
\hline Patients & $\begin{array}{c}\text { Stage at } \\
\text { diagnosis }\end{array}$ & $\begin{array}{c}\text { Clinical stage } \\
\text { before vaccination }\end{array}$ & $\begin{array}{c}\text { No. of } \\
\text { vaccination }\end{array}$ & Antigens & $\begin{array}{c}\text { Single dose } \\
\text { peptides (ug) }\end{array}$ & $\begin{array}{c}\text { CD8 } \\
\text { pre-vaccination }\end{array}$ & $\begin{array}{c}\text { CD8 post- } \\
\text { vaccination }\end{array}$ & $\begin{array}{c}\text { Clinical } \\
\text { Response }\end{array}$ \\
\hline MA09 & IV & PD & 6 & $\begin{array}{l}\text { MUC1-ErbB2- } \\
\text { CEA }\end{array}$ & 500 & Neg & Neg & PD \\
OV02 & IIIC & SD & 6 & MUC1 & 100 & Neg & Neg & PD \\
OV03 & IIIC & PD & 3 & MUC1-CEA & 100 & Neg & Neg & PD \\
OV08 & IIB & SD & 7 & MUC1 & 100 & Neg & Neg & PD \\
\hline
\end{tabular}

$\mathrm{PD}$, disease progression; SD, stady disease.

Table V. Median and range values of IFN $\gamma$ spots produced by CD8 $\mathrm{T}$ cells before and after vaccination.

\begin{tabular}{|c|c|c|c|c|}
\hline & \multicolumn{2}{|c|}{$\begin{array}{l}\mathrm{DCs}+\mathrm{CD} 8 \\
\mathrm{~T} \text { cells }\end{array}$} & \multicolumn{2}{|c|}{$\begin{array}{c}\text { DCs }+ \text { peptide }+ \\
\text { CD8 T cells }\end{array}$} \\
\hline & Median & Range & Median & Range \\
\hline \multicolumn{5}{|c|}{ Before vaccination } \\
\hline CEA & 22.5 & $8-60$ & 40 & $8-80$ \\
\hline MUC1 & 16 & $12-112$ & 18 & $7-202$ \\
\hline ErbB2 & 21 & $10-178$ & 27.5 & $9-296$ \\
\hline \multicolumn{5}{|c|}{ After vaccination } \\
\hline CEA & 31 & $12-118$ & 65 & $12-598$ \\
\hline MUC1 & 20 & $8-56$ & 15 & $8-160$ \\
\hline ErbB2 & 39 & $14-100$ & 179.5 & $12-390$ \\
\hline
\end{tabular}

Treg trends did not appear to be correlated to a clinical or immunological response. Only 2/14 patients (MA07 and OV10) showed a decrease in circulating Tregs, one in a patient who showed no response to vaccination and one who showed a strong response to two peptides (Fig. 3).

DTH skin reactions were tested by injecting $10 \mu \mathrm{g}$ of each peptide intradermal at baseline, after the sixth and after the seventh dose of vaccination for in vivo immunomonitoring. No positive reactions were detected at baseline. Five out of 14 patients developed a positive DTH to at least one peptide after the recall dose.

An OC patient enrolled in the trial suffered from lymph nodal recurrence 14 months after primary surgery. She was subjected to para-aortic lymphadenectomy. She was then submitted to II line chemotherapy and concomitantly to 3 vaccination re-boosts every 3 weeks. During the first 


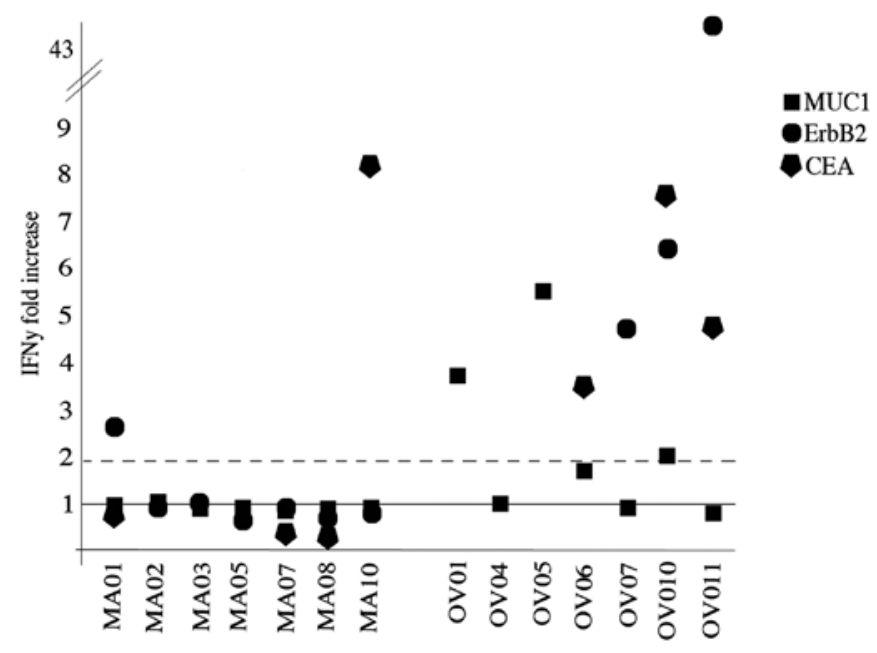

Figure 2. IFN $\gamma$ production of specific $\mathrm{CD} 8 \mathrm{~T}$ cells from vaccinated patients. ELISPOT analysis of IFN $\gamma$ released by MUC1 (square), ErbB2 (circle) and CEA (pentagon) specific CD8 T lymphocytes after two weeks of amplification. Data are reported as fold increase obtained dividing the number of IFN $\gamma$ spots produced before vaccination with those produced after the last dose. The values two fold-increased from baseline (continuous line) are considered positive.

vaccination cycle, specific IFN $\gamma$ producing $\mathrm{CD} 8^{+}$immune response to the ErbB2 and CEA peptides had increased but returned to baseline after 3 months from the treatment. After 5 months from the vaccination, at the time of relapse, specific ErbB2, CEA CD8 ${ }^{+}$circulating lymphocytes had increased (Fig. 4A). Interestingly CEA- and ErbB2-specific $\mathrm{CD} 8^{+}$lymphocytes were also identified in the removed bulky aortic lymph nodes (Fig. 4B). This suggests that although the immune response was unable to avoid recurrence, homing of specific lymphocytes occurred. A blood sample collected at 36 months from the last boost still showed specific IFN $\gamma$ producing ErbB2 and CEA CD8 ${ }^{+} \mathrm{T}$ cells (Fig. $4 \mathrm{C}$ ).

Toxicity. No ECOG grade 4 toxicity related to the study was observed. The most common adverse events were itch, erythema and tumescence (all maximum grade 2 ) in the injection site. Moreover, 6 patients referred Flu-like symptoms (all maximum grade 2) the day after vaccination dose. Only one patient developed deep venous thrombosis (grade 3) in the right leg that was managed with medical treatment (Table VI).

Survival. At a maximum of 8 years follow-up, all 7 BC patients enrolled according to protocol are alive and currently disease-free. One patient suffered from disease recurrence and was treated with surgery and adjuvant chemotherapy, she has been disease-free for 26 months. Out of the 7 OC patients enrolled, no patient has died of disease although 2 patients suffered from disease recurrence. These women were subjected to secondary cytoreduction and adjuvant chemotherapy. One of them is currently disease-free at the 1-year follow-up check-up and the other suffers from disease recurrence.

\section{Discussion}

Chemo-radio-therapy and the most recent targeted therapies have significantly improved the survival rates of different malignancies. However, survival rates remain highly unsatisfactory
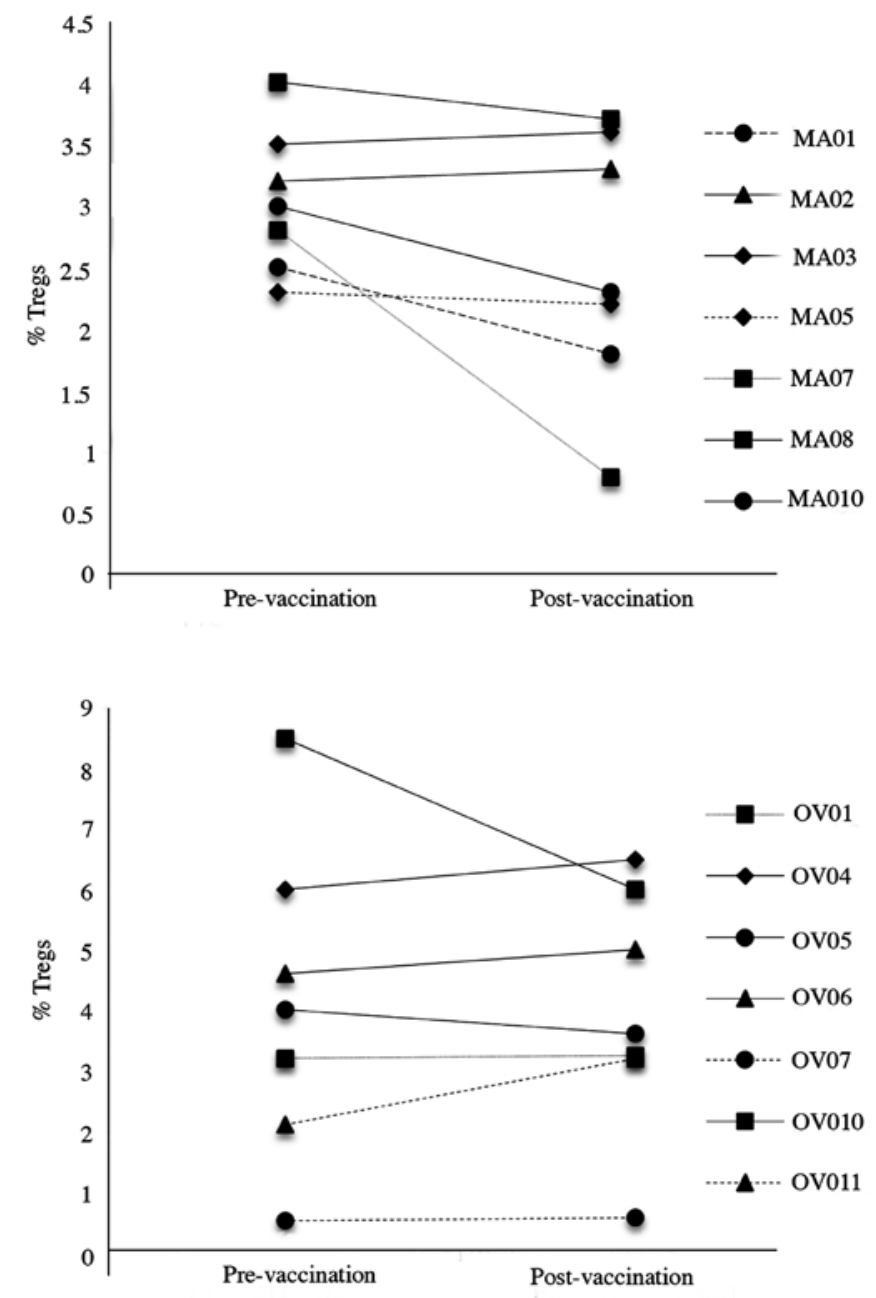

Figure 3. Circulating Treg cell analysis in $\mathrm{BC}$ and $\mathrm{OC}$ patients. Tregs were analysed by cytofluorimetry for the expression of CD4, CD25 and FOXP3 molecules. Results show $\mathrm{CD} 4{ }^{+} \mathrm{CD} 25^{+} \mathrm{FOXP} 3^{+}$cells pre- and post- vaccination. Data are reported as percentage of $\mathrm{CD} 4^{+} \mathrm{CD} 25^{+} \mathrm{FOXP} 3^{+}$cells.

and these standard options produce intense, debilitating and distressing side effects, destroying healthy tissues along with cancer cells. Consequently, there is a constant and clear unmet demand for the development of new therapeutic effective agents and strategies with minimal side effects.

In the present scenario, cancer immunotherapy appears to be a promising candidate, since clinical trials have shown positive effects on survival with minimal side effects $(15,16)$. So far, different strategies of immunoactivation have been attempted in cancer patients, mostly adopting synergic biological mechanism: peptide- or protein-based vaccinations, poxviral vectors, anti-idiotypic antibody-based vaccinations, dendritic cell- and retargeted lymphocytes. Recently, the possibilities to combine these strategies with unspecific unleashing $\mathrm{T}$ cell modulation and expansion have, moreover, increased interest in these protocols.

Among different approaches, short peptide-based vaccinations have several advantages such as good immunological efficacy, low costs and safety. Peptide tumour-associated antigens are usually 8-10 amino acids long with 2-3 primary anchor residues that interact with MHC class I-molecules and 2-3 residues which bind to $\mathrm{T}$ cell receptor $(17,18)$. Short 


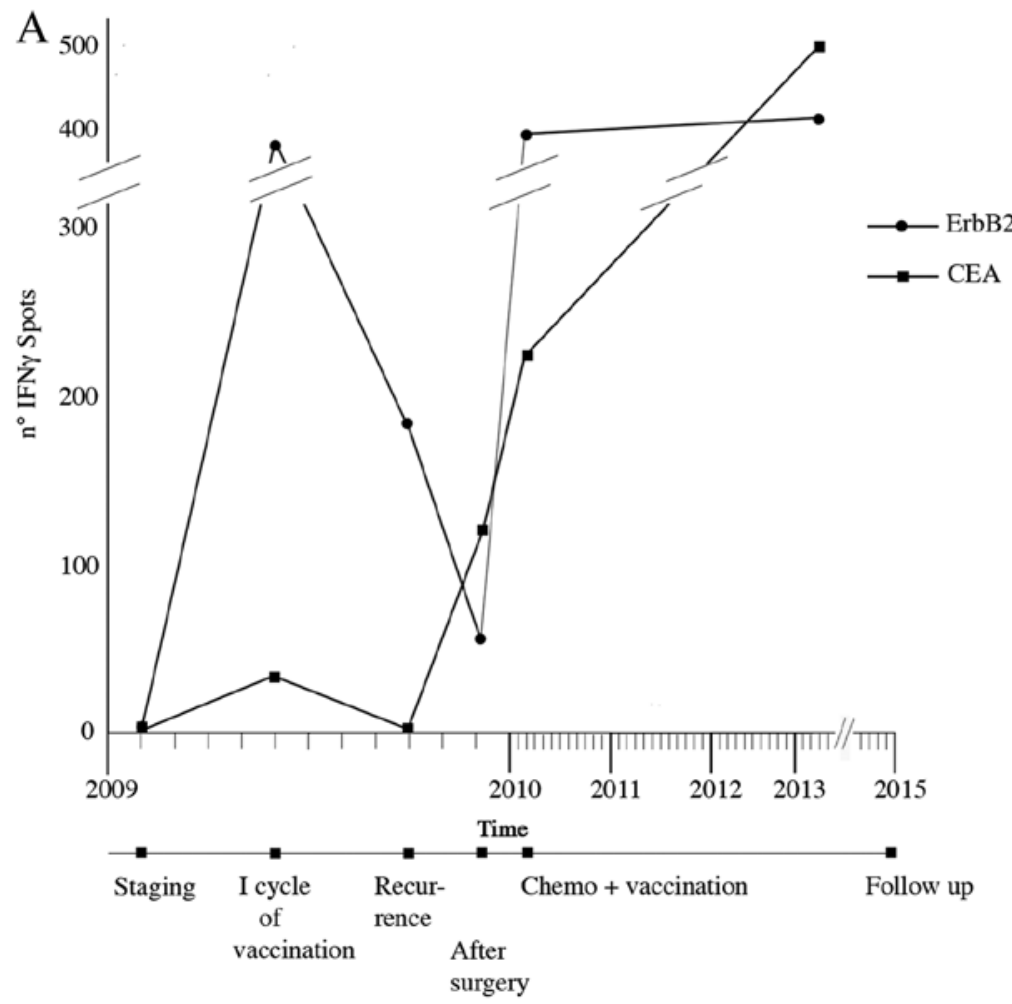

$\mathrm{B}$

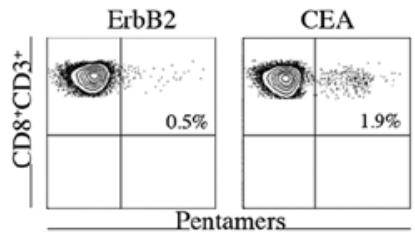

$\mathrm{C}$

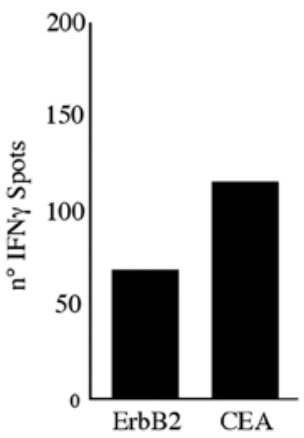

Figure 4. Immunomonitoring of OC patients. (A) Number of IFN $\gamma$ spots released by ErbB2 (circle) and CEA (square) specific CD8 T cells at staging (01/2009), after the first cycle of vaccination (04/2009), at the lymph nodal recurrence (09/2009), after the para-aortic lymphadenectomy (12/2009), after the second cycle of vaccination (04/2010) and at follow-up (03/2013). (B) ErbB2 and CEA pentamer staining performed on purified CD8 T cells obtained from bulky aortic lymph node. (C) Number of IFN $\gamma$ spots produced by ErbB2 and CEA specific CD8 T cells purified from bulky lymph node.

Table VI. Vaccine toxicity.

\begin{tabular}{|c|c|c|c|c|c|c|}
\hline & \multicolumn{6}{|c|}{ EOCG level of toxicity } \\
\hline & & 0 & 1 & 2 & 3 & 4 \\
\hline Leukopenia & $\begin{array}{l}\text { WBCx } 10^{3} ; \\
\text { lymphocytes; } \\
\text { granulocytes/ } \\
\text { bands }\end{array}$ & 18 & 0 & 0 & 0 & 0 \\
\hline Thrombocytopenia & Plt $\times 10^{3}$ & 18 & 0 & 0 & 0 & 0 \\
\hline Anemia & $\mathrm{Hgb}$ & 18 & 0 & 0 & 0 & 0 \\
\hline Coagulation & $\begin{array}{l}\text { Fibrinogen; } \\
\text { PT; PTT }\end{array}$ & 18 & 0 & 0 & 0 & 0 \\
\hline GU & Creatinine & 18 & 0 & 0 & 0 & 0 \\
\hline Liver & $\begin{array}{l}\text { Bilirubin; } \\
\text { SGOT, SGPT }\end{array}$ & 18 & 0 & 0 & 0 & 0 \\
\hline $\begin{array}{l}\text { Fever in absence } \\
\text { of infection }\end{array}$ & - & 12 & 6 & 0 & 0 & 0 \\
\hline GI & $\begin{array}{l}\text { Nausea; } \\
\text { vomiting; } \\
\text { diarrhea }\end{array}$ & 18 & 0 & 0 & 0 & 0 \\
\hline Skin & - & 0 & 14 & 4 & 0 & 0 \\
\hline Allergy & - & 17 & 1 & 0 & 0 & 0 \\
\hline Phlebitis & - & 17 & 0 & 0 & 1 & 0 \\
\hline Local & - & 16 & 2 & 0 & 0 & 0 \\
\hline Alopecia & - & 18 & 0 & 0 & 0 & 0 \\
\hline
\end{tabular}

peptides are characterized by a small size, ease of synthesis and manipulation, direct load on antigen presenting cells, and low production and administration costs (19-21). CTLs directed against peptides presented by MHC class I molecules constitute powerful effectors of the immune system against tumour cells.

In $\mathrm{BC}$, clinical experiences with peptide-based vaccinations date back to 1999 and since then $\sim 400$ women have been subjected to these types of vaccinations. Immunogenic epitopes of ErbB2 (22), MUC1 $(23,24)$ and survivin 2B (13) have been adopted. Encouraging results have derived from trials especially in using ErbB2 peptide. Unfortunately, in advanced BC setting, immunotherapy did not show any impact on the patients' clinical outcome $(25,26)$. However, promising experience in BC early disease setting has been gathered. Disease-free HLA-A2 ${ }^{+}$ breast cancer patients receiving different dose regimen of 4-6 monthly vaccinations as consolidation treatment, in fact, although presented with poorer prognostic factor compared to the control group, showed a significantly better prognosis in terms of both DFS and OS respect to disease-free HLA-A2$\mathrm{BC}$ patients not subjected to vaccination program after an average of 2 years of follow-up. Vaccinated patients showed to have developed E75-specific CD8 ${ }^{+} \mathrm{T}$ cell, still detectable 6 months after vaccination completion (27). As a consequence, previous experience of peptide-based vaccination in $\mathrm{BC}$ led us to understand that peptides are able to: i) induce a T CD4 ${ }^{+}$ and $\mathrm{T} \mathrm{CD} 8^{+}$-specific immunologic response; ii) induce epitope spreading; iii) elicit a $\mathrm{T}$ cell immunity against the vaccinated epitope and other tumour derived proteins and iv) induce a subset of memory $\mathrm{T}$ cells. 
Less experience has been gathered on OC patients, however, the results appear to be in line with those observed in breast tumours. Approximately 150 women were subjected to peptide-based vaccination beginning in 2002 (22). Most immunogenic epitopes adopted in ovarian cancer setting were found to be mixed ErbB2 peptides and NY-ESO peptide $(28,29)$. Unfortunately, most OC patients are diagnosed with an advanced stage and in this setting the high tumour burden has proved to induce systemic immunosuppression and subsequent immune system failure (10). As a consequence, the immunological exhaustion characterizing advanced OC patients was probably the limiting factor determining the absence of clinical benefit reported in the previous experience of immunotherapy trial in vaccinated OC patients.

In the present phase I/II study, the clinical safety and immune activation and modulation of consolidation therapy with a multipeptide vaccine were investigated in $14 \mathrm{BC}$ and OC patients in clinical disease remission. Multipeptide vaccination is safe and able to induce a specific IFN $\gamma$ producing $\mathrm{CD}^{+}$immune response.

OC patients showed higher immunological responses when compared to $\mathrm{BC}$ patients. This could be partially explained by the platinum based regimens adopted for OC patients that have an indirect effect on the immune system (30). Platinum-based therapies have in fact shown to enhance the immunostimulatory potential of DCs and decrease immunosuppression by depleting myeloid suppressor cells $(31,32)$. CEA modified CAP-1 peptide appeared to be the most effective in inducing cellular specific immune response, whereas MUC1 peptide epitope, adopted in human beings for the first time, and E75 were able to induce a specific immune response in, respectively, 20 and $40 \%$ of patients. It is important to highlight that these are the first data that allow a direct comparison of the same vaccination schedule in two extremely different moments of the natural history of these neoplasms. In line with the poor clinical responses reported in past trials, none of the heavily pretreated patients or patients presenting with high tumour burden showed any immunological response. Although anecdotal, the observation is promising; it was carried out in the patients whose samples from recurrent disease were available. The high percentage of vaccine specific CD $8^{+}$lymphocytes in the bulky nodes demonstrates the homing phenomenon of newly generated immune cells. Moreover, in this patient additional recalls of the vaccine were able to re-elicit further the amount of specific $\mathrm{CD}^{+} \mathrm{T}$ cells against ErbB2 and particularly to the CEA antigen that was weakly positive in the first vaccination.

Overall, although beyond the study objective, the clinical outcome of the patients enrolled in the trial appears favourable, having registered no patient deceased at an average 87 months follow-up. Several enrolled patients were affected by early disease and therefore this may justify the survival data. The prolonged follow-up and the sample size are sufficient to exclude long-term side effects or a paradoxical detrimental effect on survival.

The promising results, in line with the data observed in similar studies, the high compliance observed by the patients and the favourable toxicity profile associated with minimal costs, support future trials of peptide vaccination in clinically disease-free patients who have completed standard treatments.
In conclusion, in $\mathrm{BC}$ and $\mathrm{OC}$ patients in clinical disease remission, multipeptide vaccination is safe and able to induce a specific IFN $\gamma$ producing $\mathrm{CD} 8^{+}$immune response. In particular, OC patients appear to be more prone to activate a specific immune response most probably due to the synergy with platinum based chemotherapy.

\section{Acknowledgements}

This study was supported by PRIN 2007 (prot.n²0072LRAZJ), PRIN 2009 (prot. n²009XMZPKW), AIRC 2009 (ref. codes 9249 and 17432), FIRB (ref code RBAU01THPL_002).

\section{References}

1. Jemal A, Bray F, Center MM, Ferlay J, Ward E and Forman D: Global cancer statistics. CA Cancer J Clin 61: 69-90, 2011.

2. Chan S, Friedrichs K, Noel D, Pintér T, Van Belle S, Vorobiof D, Duarte R, Gil Gil M, Bodrogi I, Murray E, et al; 303 Study Group: Prospective randomized trial of docetaxel versus doxorubicin in patients with metastatic breast cancer. J Clin Oncol 17: 2341-2354, 1999

3. Ozols RF, Bundy BN, Greer BE, Fowler JM, Clarke-Pearson D, Burger RA, Mannel RS, DeGeest K, Hartenbach EM and Baergen R; Gynecologic Oncology Group: Phase III trial of carboplatin and paclitaxel compared with cisplatin and paclitaxel in patients with optimally resected stage III ovarian cancer: A Gynecologic Oncology Group study. J Clin Oncol 21: 3194-3200, 2003.

4. Paik S, Kim C and Wolmark N: HER2 status and benefit from adjuvant trastuzumab in breast cancer. N Engl J Med 358: 1409-1411, 2008.

5. Aydiner A and Tas F: Meta-analysis of trials comparing anastrozole and tamoxifen for adjuvant treatment of postmenopausal women with early breast cancer. Trials 9: 47, 2008..

6. Pecorelli S, Favalli G, Gadducci A, Katsaros D, Panici PB, Carpi A, Scambia G, Ballardini M, Nanni O and Conte P; After 6 Italian Cooperative Group: Phase III trial of observation versus six courses of paclitaxel in patients with advanced epithelial ovarian cancer in complete response after six courses of paclitaxel/platinum-based chemotherapy: Final results of the After- 6 protocol 1. J Clin Oncol 27: 4642-4648, 2009.

7. Zhang L, Conejo-Garcia JR, Katsaros D, Gimotty PA, Massobrio M, Regnani G, Makrigiannakis A, Gray H, Schlienger K, Liebman MN, et al: Intratumoral T cells, recurrence, and survival in epithelial ovarian cancer. N Engl J Med 348: 203-213, 2003.

8. Curiel TJ, Coukos G, Zou L, Alvarez X, Cheng P, Mottram P, Evdemon-Hogan M, Conejo-Garcia JR, Zhang L, Burow M, et al: Specific recruitment of regulatory $\mathrm{T}$ cells in ovarian carcinoma fosters immune privilege and predicts reduced survival. Nat Med 10: 942-949, 2004.

9. Mahmoud SM, Paish EC, Powe DG, Macmillan RD, Grainge MJ Lee AH, Ellis IO and Green AR: Tumor-infiltrating CD8 ${ }^{+}$ lymphocytes predict clinical outcome in breast cancer. J Clin Oncol 29: 1949-1955, 2011.

10. Napoletano C, Bellati F, Landi R, Pauselli S, Marchetti C, Visconti V, Sale P, Liberati M, Rughetti A, Frati L, et al: Ovarian cancer cytoreduction induces changes in $\mathrm{T}$ cell population subsets reducing immunosuppression. J Cell Mol Med 14: 2748-2759, 2010.

11. Bellati F, Napoletano C, Ruscito I, Visconti V, Antonilli M, Gasparri ML, Zizzari IG, Rahimi H, Palaia I, Rughetti A, et al: Past, present and future strategies of immunotherapy in gynecological malignancies. Curr Mol Med 13: 648-669, 2013.

12. Hueman MT, Stojadinovic A, Storrer CE, Dehqanzada ZA, Gurney JM, Shriver CD, Ponniah S and Peoples GE: Analysis of naïve and memory CD4 and CD8 T cell populations in breast cancer patients receiving a HER2/neu peptide (E75) and GM-CSF vaccine. Cancer Immunol Immunother 56: 135-146, 2007.

13. Tsuruma T, Iwayama Y, Ohmura T, Katsuramaki T, Hata F, Furuhata T, Yamaguchi K, Kimura Y, Torigoe T, Toyota N, et al: Clinical and immunological evaluation of anti-apoptosis protein, survivin-derived peptide vaccine in phase I clinical study for patients with advanced or recurrent breast cancer. J Transl Med 6: 24, 2008 
14. Yuan J, Gallardo HF, Rasalan T, Ranganathan R, Wang J, Zhang Y, Panageas K, Stan R, Young JW, Houghton AN, et al: In vitro expansion of Ag-specific T cells by HLA-A*0201transfected K562 cells for immune monitoring. Cytotherapy 8: 498-508, 2006.

15. Horstmann E, McCabe MS, Grochow L, Yamamoto S, Rubinstein L, Budd T, Shoemaker D, Emanuel EJ and Grady C: Risks and benefits of phase 1 oncology trials, 1991 through 2002. N Engl J Med 352: 895-904, 2005.

16. Kantoff PW, Higano CS, Shore ND, Berger ER, Small EJ, Penson DF, Redfern CH, Ferrari AC, Dreicer R, Sims RB, et al; IMPACT Study Investigators: Sipuleucel-T immunotherapy for castration-resistant prostate cancer. N Engl J Med 363: 411-422, 2010.

17. Thayer AM: Improving peptides. Chem Eng News 89: 13-20, 2011.

18. Borghouts C, Kunz C and Groner B: Current strategies for the development of peptide-based anti-cancer therapeutics. J Pept Sci 11: 713-726, 2005

19. Gao GF and Jakobsen BK: Molecular interactions of coreceptor CD8 and MHC class I: The molecular basis for functional co-ordination with the T-cell receptor. Immunol Today 21: 630-636, 2000.

20. Cho HI and Celis E: Optimized peptide vaccines eliciting extensive CD8 T-cell responses with therapeutic antitumor effects. Cancer Res 69: 9012-9019, 2009.

21. Napoletano C, Rughetti A, Landi R, Pinto D, Bellati F, Rahimi H, Spinelli GP, Pauselli S, Sale P, Dolo V, et al: Immunogenicity of allo-vesicle carrying ERBB2 tumor antigen for dendritic cell-based anti-tumor immunotherapy. Int $\mathbf{J}$ Immunopathol Pharmacol 22: 647-658, 2009.

22. Disis ML, Gooley TA, Rinn K, Davis D, Piepkorn M, Cheever MA, Knutson KL and Schiffman K: Generation of T-cell immunity to the HER-2/neu protein after active immunization with HER-2/neu peptide-based vaccines. J Clin Oncol 20: 2624 2632, 2002.

23. Musselli C, Ragupathi G, Gilewski T, Panageas KS, Spinat Y and Livingston PO: Reevaluation of the cellular immune response in breast cancer patients vaccinated with MUC1. Int J Cancer 97: 660-667, 2002.

24. Gilewski T, Adluri S, Ragupathi G, Zhang S, Yao TJ, Panageas K, Moynahan M, Houghton A, Norton L and Livingston PO Vaccination of high-risk breast cancer patients with mucin-1 (MUC1) keyhole limpet hemocyanin conjugate plus QS-21. Clin Cancer Res 6: 1693-1701, 2000.
25. Knutson KL, Schiffman K, Cheever MA and Disis ML: Immunization of cancer patients with a HER-2/neu, HLA-A2 peptide, p369-377, results in short-lived peptide-specific immunity. Clin Cancer Res 8: 1014-1018, 2002.

26. Salazar LG, Fikes J, Southwood S, Ishioka G, Knutson KL, Gooley TA, Schiffman K and Disis ML: Immunization of cancer patients with HER-2/neu-derived peptides demonstrating highaffinity binding to multiple class II alleles. Clin Cancer Res 9: $5559-5565,2003$

27. Peoples GE, Gurney JM, Hueman MT, Woll MM, Ryan GB, Storrer CE, Fisher C, Shriver CD, Ioannides CG and Ponniah S: Clinical trial results of a HER2/neu (E75) vaccine to prevent recurrence in high-risk breast cancer patients. J Clin Oncol 23: 7536-7545, 2005 .

28. Odunsi K, Qian F, Matsuzaki J, Mhawech-Fauceglia P, Andrews C, Hoffman EW, Pan L, Ritter G, Villella J, Thomas B, et al: Vaccination with an NY-ESO-1 peptide of HLA class I/II specificities induces integrated humoral and $\mathrm{T}$ cell responses in ovarian cancer. Proc Natl Acad Sci USA 104: 12837-12842, 2007.

29. Sabbatini P, Tsuji T, Ferran L, Ritter E, Sedrak C, Tuballes K, Jungbluth AA, Ritter G, Aghajanian C, Bell-McGuinn K, et al: Phase I trial of overlapping long peptides from a tumor self-antigen and poly-ICLC shows rapid induction of integrated immune response in ovarian cancer patients. Clin Cancer Res 18: 6497-6508, 2012.

30. Hato SV, Khong A, de Vries IJ and Lesterhuis WJ: Molecular pathways: The immunogenic effects of platinum-based chemotherapeutics. Clin Cancer Res 20: 2831-2837, 2014.

31. Hato SV, de Vries IJ and Lesterhuis WJ: STATing the importance of immune modulation by platinum chemotherapeutics. OncoImmunology 1: 234-236, 2012.

32. Diaz Y, Tundidor Y, Lopez A and Leon K: Concomitant combination of active immunotherapy and carboplatin- or paclitaxel-based chemotherapy improves anti-tumor response. Cancer Immunol Immunother 62: 455-469, 2013. 